\title{
ADVENTITIOUS ROOTING OF NATIVE ERICA MANIPULIFLORA SALISB., A MEDITERRANEAN ORNAMENTAL SHRUB
}

\author{
ARI, E. ${ }^{1,2^{*}}-$ GURBUZ, E. ${ }^{1,3}$

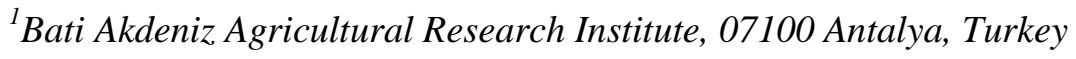 \\ ${ }^{2}$ Permanent Address: Department of Agricultural Biotechnology, Faculty of Agriculture, \\ Akdeniz University, 07058, Antalya, Turkey \\ (phonelfax: +90-242-3102451) \\ ${ }^{3}$ Permanent Address: Bartın Directorate of Provincial Food Agriculture and Livestock, Bartın, \\ Turkey \\ ${ }^{*}$ Corresponding author \\ e-mail:esinari@akdeniz.edu.tr \\ (Received $15^{\text {th }}$ July 2015; accepted $20^{\text {th }}$ Sept 2015)
}

\begin{abstract}
The use of Erica manipuliflora, a decorative native ornamental species, is limited in landscaping due to insufficient plantlet production in nurseries. The aim of study was to determine the most effective and practical adventitious rooting (AR) protocol for successful vegetative production of $E$. manipuliflora. Two experiments (Expt.) were established in November and June to reveal the effects of different substances [perlit and perlit:sphagnum peat $(1: 1 \mathrm{v} / \mathrm{v})$ in Expt.I and peat, peat:sand (1:1), cocopeat:sand (5:1) and perlite in Expt.II] and exogenous auxins including liquid (in Expt.I) and powdered (in Expt.II) formulations of IBA, NAA or combination of both. The results indicated $E$. manipuliflora cuttings taken in June and cultured in cocopeat:sand (5:1) mixture without any auxin treatment presented the highest survival (84\%) and rooting (76\%) performance. In addition, exogenous auxin usage is not essential for AR of E. manipuliflora cuttings. It can be used for the cuttings inserted in cocopeat-free media. But it exhibited reducing effect on rooting in cocopeat-based medium. The use of mycorrhizal inoculation and also minicuttings in eco friendly cocopeat-based media in future studies might increase the efficiency of E. manipuliflora AR protocol.
\end{abstract}

Keywords: auxin, cocopeat, domestication, heath, ornamental plant

Abbreviations: AR, adventitious rooting; CPA, commercial powdered auxin; Expt., experiment.

\section{Introduction}

High adoption of xeriscape approach laid out the increasing use of native plants. Today, utilization of them has been accepted as an emerging niche market (Hamill, 2005). According to Norcini (2006), the ratio of native plant sales of Florida in 2005 was $11 \%$ of all ornamental plant production. The use of native plants is an upward trend in southeastern United States since the 1990s (Waterstrat, 1997; Brzuszek and Harkess, 2009). Thanks to the other factors like growing environment consciousness, changing consumer trends and the global climate changes, this trend has progressed in other parts of the world, too. Also superior functional characteristics like resistance/tolerance to drought, saline and poor soil conditions can be mentioned as main causes in this trend.

In our previous inquiry study (Ar1 et al., 2010), we determined the perspective and tendency of the representatives of landscape sector for the use of natural plants in Antalya, Turkey. Erica manipuliflora Salisb. (Ericaceae), whorled heath, was identified as one of the most desired three native species for large quantity production and sale in the market by both 
landscape architects and nursery managers. Since it has valuable xeriscape plant characters like reducing water use and landscape maintenance cost, it is not only preferred for Antalya but also for other regions under Mediterranean climate.

Native distribution area of E. manipuliflora (synonym: E. verticillata Forssk.) (UPOV, 2015) covers a region from Croatia to Lebanon, including southeast Italy, Crete and Cyprus (Fagundez and Izco, 2011). E. manipuliflora mostly disperses up to $1500 \mathrm{~m}$ altitude of the West and South Anatolia of Turkey, particular in open fields, phrygana and macchie groups, Pinus brutia forests, limestone or serpentine layered rocks (TPDS, 2015). This evergreen, perennial shrub growing up to 1-2 $\mathrm{m}$ inhabits among the widespread woody species of macchie community in Mediterranean territory of Turkey.

E. manipuliflora is a phanerophyt species (TPDS, 2015) that blooms scented (Jones, 1987) and nectar producing flowers with 1-5 in axillary umbels on very short shoots (THS, 2015a) varying from white to dark pink, shades of lilac color between May and November. It has flowers with 8 stamens and 4 corolla lobes and sepals (Stevens, 1978; Güvenç and Kendir, 2012), which are partially fused and bell-shaped, papillate anthers, crystals on the mesophyll and occasionally a sparsely hairy ovary top. Its ellipsoid seeds reach up to $0.8 \mathrm{~mm}$ long (Fagundez and Izco, 2011) while needle-like short leaves in whorls of 3 or 4 grow up to $9 \mathrm{~mm}$ long (THS, 2015a). Aerials parts of E. manipuliflora have been ethnobotanically utilized for preparation of herbal teas as astringent, diuretic and remedy of urinary infections in Turkey (Baytop, 1999; Tuzlaci and Eryasar Aymaz, 2001; Akkol et al., 2008). On the other hand, it can be used also for apiculture making benefit of abundant flowers. However, the main interest for E. manipuliflora is for its ornamental value. This attractive species can be used as group or ground-cover plant in landscaping. It has gained more importance for conservation of ecosystems due to its less water and fertilizer need because of the ability to grow in arid and barren lands. The latest demand for E. manipuliflora has been improved by the greenkeepers of golf courses in Antalya lately. This formable species is desirable to cover small hills since it is likely to control the plant size and flowering period of $E$. manipuliflora by pruning.

In order to provide this plant species in large quantities, it should be domesticated and domestication of E. manipuliflora is also important for the sustainable assessment and exploitation of an underused genetic resource. The first step for domestication is to establish the production systems. It is possible to produce E. manipuliflora via generative or vegetative methods. In generative production, germination is not consistent as in other Ericaceous plants species whose germination is often variable and not well defined (Englert et al., 1996). In our previous germination study (Ari et al., 2014), only 8 seedlings could be produced from $0.10 \mathrm{~g}$ seeds sown by scattering and without prechilling. Pipinis et al. (2006) also sowed E. manipuliflora seeds with scattering and achieved 181 seedlings from $0.15 \mathrm{~g}$ seeds treated one month of prechilling. In addition, Piotto et al. (2003) reported the seeds of E. arborea, a close relative species of $E$. manipuliflora, could be germinated after being exposed to smoke and high temperatures up to $120^{\circ} \mathrm{C}$ for 10 minutes. Seemingly, extra treatments might be needed for germination of E. manipuliflora seeds. On the other hand, the individual plants which would be derived from native seeds will exhibit segregation in their phenotypes. Moreover, a high morphological variability was reported for E. manipuliflora (McClintock, 1989). However, different vegetative production methods have the advantage to supply mass clonal plant production which is important especially for the reproduction of unique plants with distinguished plant characteristics, and also of the mutant genotypes.

The adventitious rooting (AR) of cuttings is the most widely used vegetative production method for woody ornamental plants. There are many factors affecting AR ratio such as plant 
growth regulator (PGR) type and concentrations, rooting substrates and environmental conditions. Among them, substrate is one of the most important factors. A good substrate should ensure the correct degree of moisture for cutting base while allowing aeration, besides holding the cutting in place (Hartmann et al., 2010; Fornes et al., 2013). Sphagnum peat moss, vermiculite, perlite, sand, clay, coconut peat, and composting of forest waste, and manure, etc, are among the wide variety of inorganic and organic materials for composing different types of growing media used in nursery cultures (Vallejo et al., 2012).

On the other side, exogenous auxins also have a big role in determination of AR capacity (Kotis et al. 2009; Ling et al. 2013). The most common used exogenous auxin is indole-3butyric acid (IBA) because of its higher root inducing capability. $\alpha$-naphthalene acetic acid (NAA) is another preferred exogenous auxin. Beside the usage of exogenous auxin alone, combinations of two auxins or auxin and cytokinin have also been used. IBA and NAA are widely preferred for auxin combination owing to their consistency in stimulating AR of cuttings (Hartmann et al., 2010).

Most of the nursery growers use commercial powdered rooting hormones since they are more practical and accessible compared to the experimental pure PGRs used generally in liquid formulations. Thus, it might be more useful to suggest to growers the more accessible production materials.

The main purpose of this study was to establish the most effective and practical AR protocol for successful vegetative production of native E. manipuliflora. For this purpose, it was focused on determination of the effects of different rooting substances and exogenous auxins including liquid and powdered formulations on rooting abilities and growth of $E$. manipuliflora cuttings.

\section{Materials and Methods}

\section{Plant Material}

The study was performed in Bati Akdeniz Agricultural Research Institute (BATEM) in Aksu (lat. $36^{\circ} 56^{\prime} \mathrm{N}$, long. 30 53'E), Antalya, Turkey, in 2008-2009. Donor E. manipuliflora plants were located in Kumkoy, Aksu, under Mediterranean environment with dry, hot summers and mild, wet winters. The climatic parameters of the months when the cuttings were sampled for two experiments were presented in Table 1. The soil type of donor plants was sandy with $32.8 \% \mathrm{CaNO}_{3}$ ingredient, $2 \%$ organic matter content, electrical conductivity (EC) of $75 \mu \mathrm{S} \mathrm{cm} \mathrm{cm}^{-1}, \mathrm{pH} 7.7$, available phosphorus (P) level of $4 \mathrm{mg} \mathrm{kg}^{-1}$, changeable potassium (K) level of $29 \mathrm{mg} \mathrm{kg}^{-1}$, changeable calcium (Ca) level of $1987 \mathrm{mg} \mathrm{kg}^{-1}$, changeable magnesium $(\mathrm{Mg})$ level of $94 \mathrm{mg} \mathrm{kg}^{-1}$.

Table 1. The meteorological data* of the months when the cuttings were sampled from donor plants of Erica manipuliflora.

\begin{tabular}{|c|c|c|}
\hline Parameters & November & $\begin{array}{l}\text { June } \\
20009\end{array}$ \\
\hline Mean minimum air temperature $\left({ }^{0} \mathrm{C}\right)$ & 10.7 & 18.8 \\
\hline Mean maximum air temperature $\left({ }^{0} \mathrm{C}\right)$ & 23.2 & 33.7 \\
\hline Mean air temperature $\left({ }^{0} \mathrm{C}\right)$ & 16.2 & 26.5 \\
\hline Mean relative humidity (\%) & 79.0 & 63.7 \\
\hline Total precipitation (mm) & 29.0 & - \\
\hline Mean maximum precipitation $(\mathrm{mm})$ & 14.6 & - \\
\hline Mean wind speed $\left(\mathrm{m} \cdot \mathrm{s}^{-1}\right)$ & 1.6 & 2.1 \\
\hline
\end{tabular}

*: The meteorological data were taken from TSMS (2015) 


\section{Rooting Experiments}

Two experiments (Expt.) were established to determine the effects of different rooting substrates and exogenous auxin types and concentrations on AR of $E$. manipuliflora cuttings. Both experiments were set up in completely randomized design in varying numbers of factorial arrangements. The long semi hardwood shoot cuttings were gathered from a well branched, vigorous E. manipuliflora population which consisted from a few uniform shrubs adjacent side by side due to the requirement of high number of cuttings for the experiments. The long cuttings carrying little fresh shoots with light green needle-like leaves were moved to glasshouse within one hour, then immediately shortened to small pieces with sharp pruning shears. The cuttings were $0.5-1 \mathrm{~cm}$ in diameter and 10-15 $\mathrm{cm}$ length and had at least 5-6 leaf nodes. They were inserted in $\approx 4-5 \mathrm{~cm}$ depth into the rooting benches with $20 \mathrm{~cm}$ height containing different substrates. The benches were bottom heated at $21^{\circ} \mathrm{C}$ in Expt. I. The irrigation of cuttings was supplied with an intermittent misting system controlled by a timer. Cycles of mist were arranged based to changing climatic conditions of glasshouse and cuttings' requirement. No fertilizer was treated to cuttings.

\section{Expt. I}

Expt. I. was set up on 10 November to determine substantially the effects of different auxin concentrations in liquid formulations in either alone or combinations on rooting of E.manipuliflora cuttings in two substrates. The experiment was in a $2 \times 10$ (substrate $\mathrm{x}$ hormone) factorial arrangement with 3 replications, 30 cuttings in each, a total of 1.800 cuttings. The basal ends of the cuttings were quick dipped for $10 \mathrm{~s}$ into the different auxin solutions of IBA and NAA (Merck, Darmstadt, Germany) alone and the combinations of IBA and NAA. IBA was dissolved in $96 \%$ ethanol (Merck), and then diluted to different concentrations while NAA in $0.1 \mathrm{~N} \mathrm{NaOH}$. The tested hormone concentrations were; 1) control, 2) $1000 \mathrm{mg} \mathrm{l}^{-1}$ IBA, 3) $2000 \mathrm{mg} \mathrm{l}^{-1}$ IBA, 4) $4000 \mathrm{mg} \mathrm{l}^{-1}$ IBA, 5) $2000 \mathrm{mg} \mathrm{l}^{-1} \mathrm{NAA}$, 6) $4000 \mathrm{mg} \mathrm{l}^{-1} \mathrm{NAA}$, 7) $8000 \mathrm{mg} \mathrm{l}^{-1} \mathrm{NAA}$, 8) $1000+500 \mathrm{mg}$ $\mathrm{l}^{-1} \mathrm{IBA}+\mathrm{NAA}$, 9) $\left.2000+1000 \mathrm{mg} \mathrm{l}^{-1} \mathrm{IBA}+\mathrm{NAA}, 10\right) 4000+2000 \mathrm{mg} \mathrm{l}^{-1} \mathrm{IBA}+$ NAA. The control cuttings were immersed in distilled water. After air dried $\approx 10 \mathrm{~min}$, the treated cuttings were stuck in perlit (Etiper, Izmir, Turkey) or the mixture $(1: 1 \mathrm{v} / \mathrm{v})$ of perlit and sphagnum peat (Klasmann-Deilmann GmbH, Geeste, Germany), which was denominated as peat hereafter, in the heated rooting benches. Peat was not used alone due to its inefficiency which was experienced in our previous works with different auxin solutions. All the cuttings were pulled out on 26 May to make observation. The survived and rooted cuttings were counted, and then other important parameters representing root and shoot growth of the cuttings were recorded. These parameters included root length $(\mathrm{cm})$, shoot number $(\mathrm{n})$ and the density of shoot and root. "Density" means the degree of shoot and root developments. This parameter was scored based on a 1-5 visual rating scale, where $1=$ very poor, $2=$ poor, $3=$ medium, $4=$ good, 5 = very good.

Besides these treatments, a small-scale treatment was set up in the same day in order to see the effect of a commercial powdered rooting hormone (Mass Plant, Adana, Turkey) containing $0.5 \%$ IBA $+0.5 \%$ NAA. This treatment had 4 replications, in each of which 30 cuttings were placed into perlite media. 


\section{Expt. II}

This experiment was set up on 09 June based largely on the results of Expt.I to determine the effects of different substrates and commercial powdered auxins (CPA) on rooting of E. manipuliflora cuttings. The experiment was performed in a 4 x 3 (substrate $\mathrm{x}$ hormone) factorial design with 5 replications, 10 cuttings in each (a total of 600 cuttings). All of the fresh semi hardwood cuttings were firstly immersed in distilled water. After air dried $\approx 10 \mathrm{~min}$, cuttings excluding the control ones were treated with one of two CPA. The first CPA (I.CPA) contained 0.5\% IBA (Rhizopon AA, Hazerswoude-Rijndijk, Netherlands) and the second CPA (II.CPA) had 0.5\% IBA + $0.52 \%$ NAA content (Mass Plant, mentioned above). Treated cuttings were inserted into 4 substrates; 1) peat, mentioned above, 2) mixture of peat and sand (1-3 mm coarse river sand) $(1: 1 \mathrm{v} / \mathrm{v}), 3)$ mixture of cocopeat (Dutch Plantin, Boekel, Nederland) and sand (5:1 v/v) and 4) perlite media. The cuttings were harvested on 10 August to record the rooting results. Only survival and rooting performances were evaluated in Expt. II.

\section{Statistical analysis}

The data of both experiments were first subjected to Levene's test to detect the variance homogeneity. Two-way and also one-way, if required, variance analysis (ANOVA) were implemented for homogeneous variances by General Linear Model procedures to test treatment differences. The means were separated by Tukey's multiple range test using SPSS software (IBM Corp., Armonk, NY, USA) at an alpha 0.05 level. For non-homogeneous survival and rooting percentages of the cuttings, the ratios were transformed using arcsine of the square root to increase homogeneity before analysis. The presented means were based on nontransformed data.

\section{Results}

\section{Expt. I}

The two-way ANOVA of Expt. I indicated very significant difference $(p<0.001)$ within two substrates (perlite and perlite:peat) for all observation parameters except root length, which was significant at $p<0.05$ (Table 2). The cuttings in perlite media presented superior performance than those of in perlite:peat media $(1: 1 \mathrm{v} / \mathrm{v})$ for survival (56.44\% versus $36.44 \%)$ and rooting $(56.44 \%$ versus $36.11 \%)$ ratios, root length $(9.87$ $\mathrm{cm}$ versus $8.90 \mathrm{~cm})$, shoot number (12.25 versus 3.71$)$ and densities for shoot (3.63 versus 2.78) and root (3.66 versus 2.92). Meantime, survival and rooting ratios of the cuttings were determined to be almost the same.

Auxin treatments exhibited very significant difference $(p \leq 0.001)$ for only survival and rooting ratios of cuttings, while they showed insignificance for other observation parameters (Table 2). Of the auxin treatments, the treatment of $4000 \mathrm{mg} \mathrm{l}^{-1}$ IBA significantly generated the highest average survival and rooting ratio $(67.8 \%)$ regardless of substrate, which followed by the treatment of $2000+1000 \mathrm{mg} \mathrm{l}^{-1} \mathrm{IBA}+$ NAA $(60.6 \%)$. IBA + NAA treatments displayed higher performance than alone IBA or NAA treatments for the other cutting growth parameters. The highest shoot number (10.4) and both shoot (3.47) and root (3.56) densities occurred in the treatment of $4000+2000 \mathrm{mg}$ $1^{-1}$ IBA + NAA, while the highest root length $(10.83 \mathrm{~cm})$ in the treatment of $2000+$ $1000 \mathrm{mg} \mathrm{l}^{-1}$ IBA + NAA. As for interactions between substrate and auxin treatments, there could not be found significant difference for any of observation parameters. 
Table 2. Effects of different substrates and liquid auxin formulations on survival, rooting and other growth parameters of Erica manipuliflora cuttings in Expt.I.

\begin{tabular}{|c|c|c|c|c|c|c|c|}
\hline & & Survival & Rooting & Root length & Shoot & Dens & ity ${ }^{1}$ \\
\hline & & $\begin{array}{c}(\%) \\
\mathbf{M} \pm \mathbf{S E}^{2}\end{array}$ & $\begin{array}{c}(\%) \\
M \pm S E\end{array}$ & $\begin{array}{c}(\mathbf{c m}) \\
\mathbf{M} \pm \mathbf{S E}\end{array}$ & $\begin{array}{l}\text { number } \\
\mathbf{M} \pm \mathbf{S E}\end{array}$ & $\begin{array}{c}\text { Shoot } \\
\mathbf{M} \pm \text { SE }\end{array}$ & $\begin{array}{c}\text { Root } \\
\mathbf{M} \pm \text { SE }\end{array}$ \\
\hline Substrate & & & & & & & \\
\hline & Perlit & $56.44 \pm 2.66 \mathrm{a}$ & $56.44 \pm 2.66 \mathrm{a}$ & $9.87 \pm 0.27 \mathrm{a}$ & $12.25 \pm 0.60 \mathrm{a}$ & $3.63 \pm 0.09 \mathrm{a}$ & $3.66 \pm 0.07 \mathrm{a}$ \\
\hline & Perlit:peat (1:1) & $36.44 \pm 3.64 \mathrm{~b}$ & $36.11 \pm 3.63 \mathrm{~b}$ & $8.90 \pm 0.32 \mathrm{~b}$ & $3.71 \pm 0.30 \mathrm{~b}$ & $2.78 \pm 0.15 b$ & $2.92 \pm 0.10 \mathrm{~b}$ \\
\hline Auxin (mg l & & & & & & & \\
\hline Control & 0 & $46.67 \pm 7.45 \mathrm{ab}$ & $45.00 \pm 7.78 \mathrm{ab}$ & $9.32 \pm 0.42 \mathrm{a}$ & $7.91 \pm 2.46 \mathrm{a}$ & $3.14 \pm 0.46 \mathrm{a}$ & $3.25 \pm 0.39 \mathrm{a}$ \\
\hline & 1000 & $38.33 \pm 4.92 b$ & $38.33 \pm 4.92 b$ & $8.03 \pm 0.68 \mathrm{a}$ & $6.38 \pm 1.68 \mathrm{a}$ & $2.89 \pm 0.32 \mathrm{a}$ & $3.14 \pm 0.17 \mathrm{a}$ \\
\hline & 2000 & $46.11 \pm 11.59 \mathrm{ab}$ & $46.11 \pm 11.59 \mathrm{ab}$ & $9.30 \pm 0.39 \mathrm{a}$ & $7.85 \pm 2.31 \mathrm{a}$ & $3.27 \pm 0.57 \mathrm{a}$ & $3.22 \pm 0.39 \mathrm{a}$ \\
\hline & 4000 & $67.78 \pm 9.05 \mathrm{a}$ & $67.78 \pm 9.05 \mathrm{a}$ & $8.67 \pm 0.80 \mathrm{a}$ & $7.96 \pm 2.37 \mathrm{a}$ & $3.08 \pm 0.31 \mathrm{a}$ & $3.39 \pm 0.21 \mathrm{a}$ \\
\hline NAA & & & & & & & \\
\hline & 2000 & $56.67 \pm 5.64 \mathrm{ab}$ & $56.67 \pm 5.64 \mathrm{ab}$ & $9.45 \pm 0.70 \mathrm{a}$ & $8.45 \pm 2.64 \mathrm{a}$ & $3.13 \pm 0.38 \mathrm{a}$ & $3.12 \pm 0.26 \mathrm{a}$ \\
\hline & 4000 & $41.67 \pm 7.59 \mathrm{ab}$ & $41.67 \pm 7.59 \mathrm{ab}$ & $9.41 \pm 0.80 \mathrm{a}$ & $6.20 \pm 1.84 \mathrm{a}$ & $3.08 \pm 0.35 \mathrm{a}$ & $3.13 \pm 0.24 \mathrm{a}$ \\
\hline & 8000 & $36.11 \pm 8.75 b$ & $36.11 \pm 8.75 b$ & $9.23 \pm 0.17 \mathrm{a}$ & $6.97 \pm 1.57 \mathrm{a}$ & $3.07 \pm 0.16 \mathrm{a}$ & $3.17 \pm 0.10 \mathrm{a}$ \\
\hline IBA+NAA & & & & & & & \\
\hline & $1000+500$ & $34.44 \pm 5.14 b$ & $34.44 \pm 5.14 b$ & $10.19 \pm 0.89 \mathrm{a}$ & $7.55 \pm 1.37 \mathrm{a}$ & $3.46 \pm 0.19 \mathrm{a}$ & $3.47 \pm 0.27 \mathrm{a}$ \\
\hline & $2000+1000$ & $60.55 \pm 6.58 \mathrm{ab}$ & $60.55 \pm 6.58 \mathrm{ab}$ & $10.83 \pm 0.56 \mathrm{a}$ & $10.15 \pm 2.15 \mathrm{a}$ & $3.45 \pm 0.19 \mathrm{a}$ & $3.45 \pm 0.14 \mathrm{a}$ \\
\hline & $4000+2000$ & $36.11 \pm 4.16 b$ & $36.11 \pm 4.16 \mathrm{~b}$ & $9.40 \pm 0.99 \mathrm{a}$ & $10.39 \pm 2.63 \mathrm{a}$ & $3.47 \pm 0.25 \mathrm{a}$ & $3.56 \pm 0.26 \mathrm{a}$ \\
\hline Significance & & & & & & & \\
\hline Substrate (S) & & $* * *$ & $* * *$ & $*$ & $* * *$ & $* * *$ & $* * *$ \\
\hline Auxin (A) & & **** & $* * *$ & NS & NS & NS & NS \\
\hline $\mathrm{S} \times \mathrm{A}$ & & NS & NS & NS & NS & NS & NS \\
\hline
\end{tabular}

When IBA and NAA treatments were dealt with separately, IBA alone treatments were found more stimulant than NAA alone treatments to produce higher survival, rooting and other observation parameters except from root length and shoot density. The average values of IBA versus NAA treatments were $50.74 \% / 44.82 \%$ for both survival and rooting ratio, $9 \mathrm{~cm} / 9.36 \mathrm{~cm}$ for root length, $7.40 / 7.21$ for shoot number, 3.08 / 3.09 for shoot density and $3.25 / 3.14$ for root density, irrespective of the substrate factor. Meanwhile, the average shoot number (7.91) and shoot density (3.14) of the control treatments were superior to those of both IBA and NAA alone treatments. In addition, the rooting ratio (45\%) and root density (3.25) of the controls were higher than NAA treatments, while the root length (9.32) was higher than IBA treatments.

The most important observation parameter in this study is AR ratio of the cuttings. Even though the interaction between substrates and auxin concentrations was found nonsignificant for this parameter, the separate one-way variance analysis was performed to show the difference between auxin treatments in each substrate. The analysis results were presented in Fig. 1 .

The highest rooting ratio $(71.11 \%)$ was determined in the cuttings treated with 4000 mg $1^{-1}$ IBA in perlite:peat $(1: 1 \mathrm{v} / \mathrm{v})$ at $p<0.05$ (Fig. 1). The same ratio was also observed in the treatment of $2000+1000 \mathrm{mg} \mathrm{l}^{-1}$ IBA + NAA in perlite. However, it is not possible to mention statistically about a given favorable influence of exogenous auxin treatments on AR in perlite media $(p=0.89)$ since the control treatment $(58.8 \%)$ without auxin exhibited higher rooting performance than 4 different auxin treatments in perlite medium. In addition, performance of control treatment $(35.6 \%)$ in perlite:peat $(1: 1 \mathrm{v} / \mathrm{v})$ media exceeded those of five auxin treatments in the same substrate. 


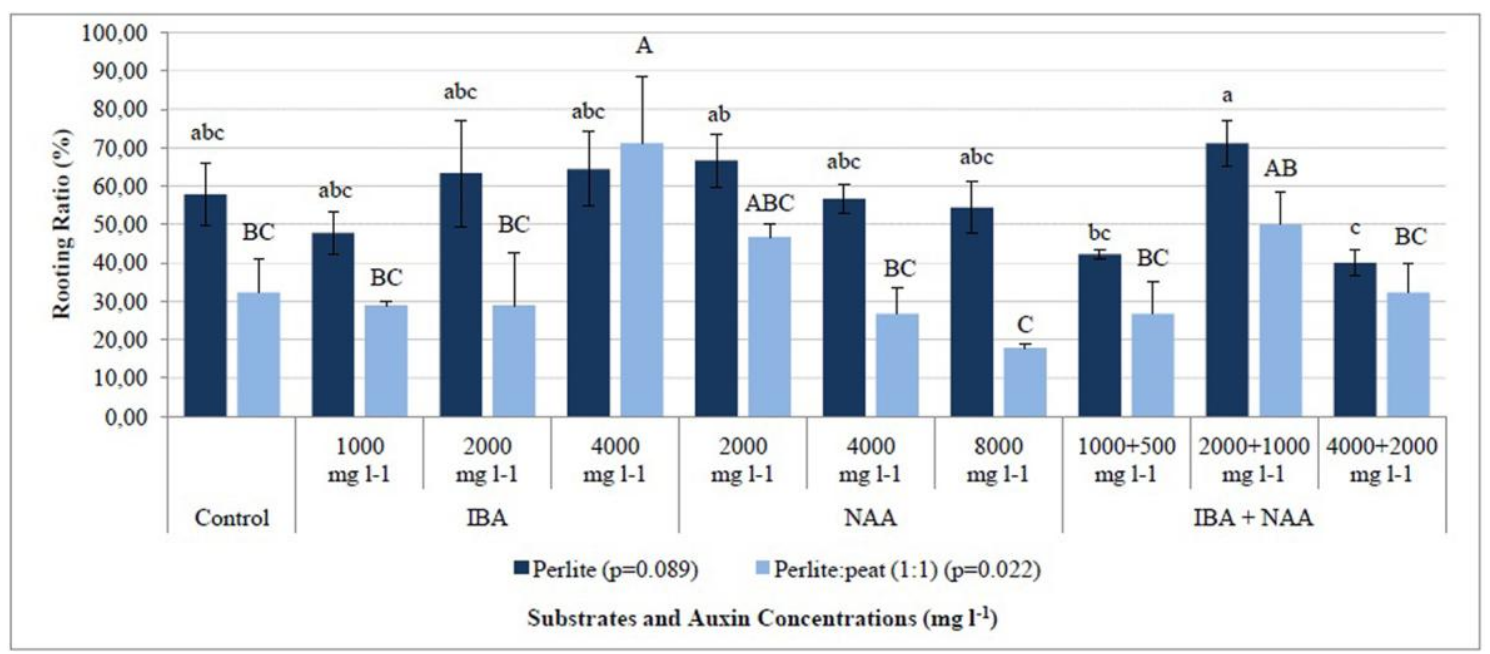

Figure 1. Effects of different liquid auxin formulations on adventitious rooting ratios (\%) of Erica manipuliflora cuttings in the substrates of perlite and perlite:peat $(1: 1 \mathrm{v} / \mathrm{v})$ in Expt. I (values are mean $(M)$ and \pm standard error (SE) bars. Comparison of means in each substrate was determined by separate one-way ANOVA, then TUKEY post hoc test. Means within each substrate followed by the same letter are not significantly different at $p \leq 0.05$ ).

Meanwhile, rooting ratio of the small-scale rooting treatment in which a commercial powdered auxin (Mass Plant) consisting from 0.5\% IBA $+0.5 \%$ NAA ingredient was tested in perlite medium was determined as $35.8 \%$. Since the experimental conditions of this rreatment were different, its result was not analyzed statistically together with those of the treatments of Experiment I. Its average rooting ratio (35.8\%) was also higher than that of seven liquid auxin treatments in perlite:peat $(1: 1)$ medium.

As for the results of other observation parameters in each substrates, they were presented here only in the text, not in a Table or Figure: The longest average root lengths were obtained from the cuttings treated with $2000+1000 \mathrm{mg} \mathrm{l}^{-1}$ IBA + NAA both in perlite and perlite:peat media $(11.41 \mathrm{~cm}$ and $10.25 \mathrm{~cm}$, respectively). The same auxin combination in perlite:peat media formed the highest average shoot numbers (5.85). However, the treatment of $4000+2000 \mathrm{mg} \mathrm{l}^{-1}$ IBA + NAA in perlite media produced superior performance (15.41) for the same parameter. Regarding the densities over 5 according to a 1-5 visual rating scale, the highest shoot and root intensity (3.53 and 3.30, respectively) in perlite:peat media were detected in the treatment of $1000+$ $500 \mathrm{mg}^{-1} \mathrm{IBA}+\mathrm{NAA}$ combination. Whereas, the most vigorous shoot and root development of the experiment occurred in perlite. The best root density (4.07) was achieved from the treatment of $4000+2000 \mathrm{mg} \mathrm{l}^{-1}$ IBA + NAA in the same substrate. Interestingly, the most shoot density (4.12) was determined in the control treatment without auxin again in the same medium.

Taken into consideration of all the results of Expt.I, growing substrates appear more effective than liquid auxin treatments on survival and rooting ratios and the other growing parameters of E. manipuliflora cuttings, as presented in Table 2.

\section{Expt. II}

According to two-way ANOVA results of Expt. II, the difference among four substrates was found very significant $(p<0.001)$ for both survival and rooting percentage (Table 3). 
Table 3. Effects of different substrates and commercial powdered auxins (CPA) on survival and rooting ratios (\%) of Erica manipuliflora cuttings in Expt.II.

\begin{tabular}{|c|c|c|c|c|}
\hline & & $\begin{array}{c}\text { Survival (\%) } \\
\quad \mathbf{M} \pm \mathbf{S E}^{1}\end{array}$ & $\begin{array}{c}\text { Rooting (\%) } \\
M \pm \text { SE }\end{array}$ & \\
\hline \multicolumn{5}{|l|}{ Substrate } \\
\hline & Peat & $11.33 \pm 3.36 c^{x}$ & $1.33 \pm 0.91$ & $\mathrm{c}$ \\
\hline & Peat:sand (1:1) & $22.67 \pm 4.62 \mathrm{bc}$ & $5.33 \pm 2.15$ & $\mathrm{bc}$ \\
\hline & Cocopeat:sand $(5: 1)$ & $54.67 \pm 7.03 \mathrm{a}$ & $43.33 \pm 8.01$ & $\mathrm{a}$ \\
\hline & Perlite & $30.00 \pm 4.14 \mathrm{~b}$ & $18.00 \pm 4.49$ & $\mathrm{~b}$ \\
\hline \multicolumn{5}{|l|}{ CPA } \\
\hline & Control & $36.50 \pm 7.26 \mathrm{a}$ & $25.50 \pm 7.52$ & $\mathrm{a}$ \\
\hline & I. CPA & $32.50 \pm 4.03 \mathrm{a}$ & $16.00 \pm 4.32$ & $a b$ \\
\hline & II. CPA & $20.00 \pm 4.23 \mathrm{~b}$ & $9.50 \pm 3.28$ & $\mathrm{~b}$ \\
\hline \multicolumn{5}{|l|}{ Significance } \\
\hline Substrate (S) & & $p=0.000 * * *$ & $p=0.000 * * *$ & \\
\hline $\mathrm{CPA}$ & & $p=0.003 * *$ & $p=0.005 * *$ & \\
\hline $\mathrm{S} \times \mathrm{CPA}$ & & $p=0.001 * * *$ & $p=0.001 * * *$ & \\
\hline
\end{tabular}

Of the four substrates, cocopeat:sand $(5: 1 \mathrm{v} / \mathrm{v})$ was the best to exhibit the highest survival $(54.7 \%)$ and rooting $(48.3 \%)$ performance, followed by perlite $(30 \%$ and $18 \%)$, irrespective of CPA (Table 3). The peat based substrates, peat:sand $(1: 1 \mathrm{v} / \mathrm{v})$ and peat alone, resulted in the lowest survival (11.3\% and $22.7 \%$, respectively) and rooting ratios (1.3\% and $5.3 \%$, respectively).

The difference among the CPAs was significant at $p<0.01$ for survival and rooting percentage (Table 3). However, this difference derived from control treatment without auxin. It was superior in terms of survival (36.5\%) and rooting $(25.5 \%)$ percentages compared to both I.CPA with IBA content, and II.CPA containing IBA+NAA combination. Meantime, I.CPA was better than II.CPA for survival (32.5\% versus $20 \%)$ and rooting $(16 \%$ versus $9.5 \%)$ ratios.

Due to the significant $(p \leq 0.001)$ interaction between substrate and CPA, separate one-way variance analysis was performed to show the difference between CPAs in each substrate for AR performance of cuttings, the results of which were presented in Fig. 2.

Overall, the control treatment in cocopeat:sand $(5: 1 \mathrm{v} / \mathrm{v})$ was significantly $(p<0.01)$ the most responsive application for AR formation (76\%), while there was no difference between two CPAs in the same substrate (30\% and 24\%) (Fig. 2). Also, no difference could be found between the CPAs including control treatment in other growing substrates. On the other hand, the survival ratio of control cuttings in cocopeat:sand medium was $84 \%$, while $44 \%$ and $36 \%$, respectively, in the cuttings treated with I. and II.CPA, in the same substrate. As an additional observation, the root structures generated in cocopeat:sand mixture was much more powerful and intensive than that of other substrates. Therefore, these results revealed the superiority of the mixture of cocopeat:sand (5:1) medium in producing vigorous roots from E. manipuliflora cuttings. Furthermore, there is no need to use CPA for successful vegetative production of this native species in cocopeat:sand medium. 


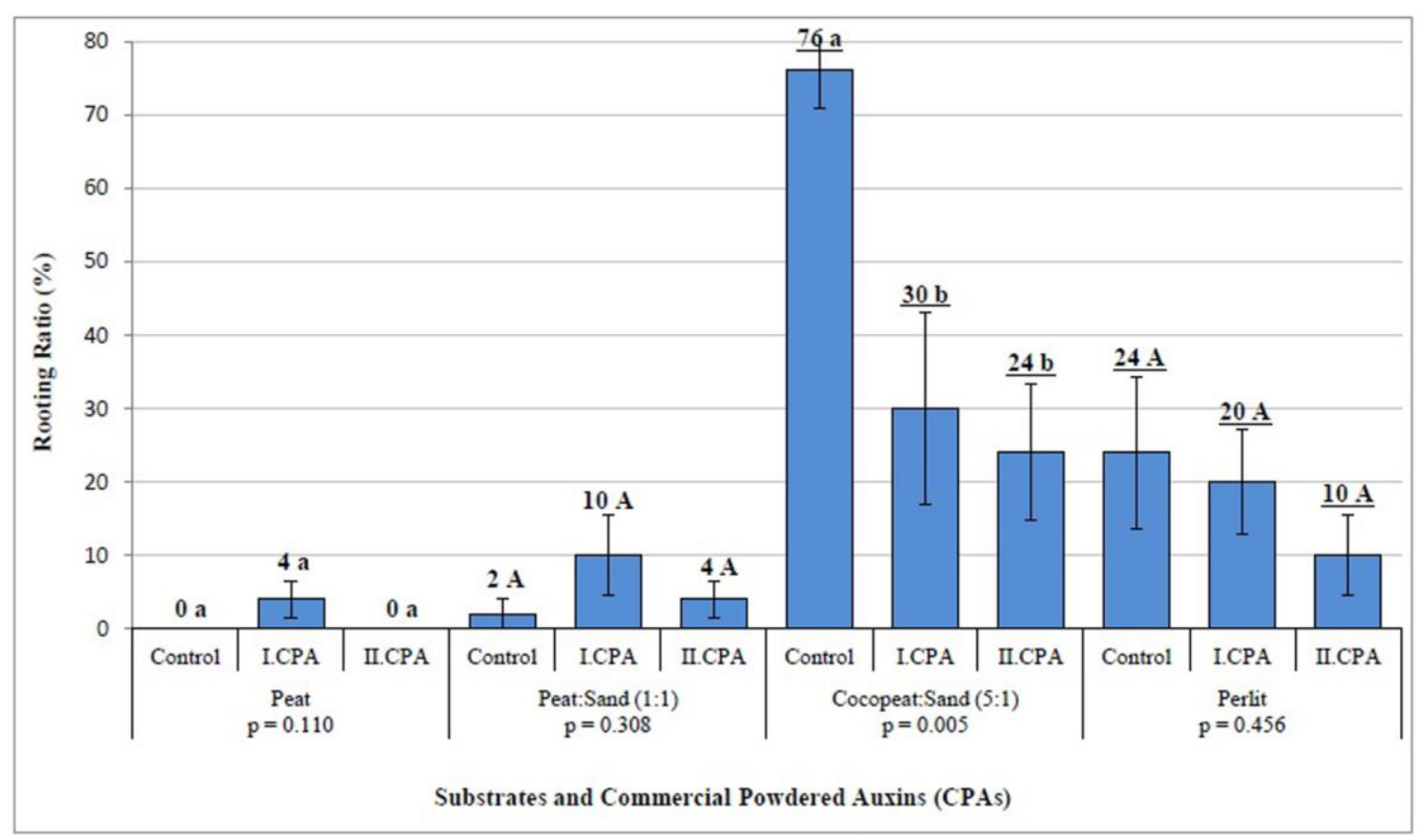

Figure 2. Effects of different commercial powdered auxins (CPAs) on adventitious rooting of

Erica manipuliflora cuttings in different substrates in Expt. II (Values are mean (M) and \pm standard error (SE) bars. Comparison of the means in each substrate was estimated by separate one-way ANOVA, then TUKEY post hoc test. Means within each substrate followed by the same letter are not significantly different at $p \leq 0.05$ ).

\section{Discussion}

Two experiments were performed to reveal the most effective AR protocol for successful vegetative production of native E. manipuliflora. Expt. I was set up on 10 November to investigate the effects of ten different liquid auxin formulations on rooting of the cuttings cultured in two rooting substrates, perlite and perlite:peat. Significant difference $(p<0.001)$ was determined among both substrates and the liquid auxin formulations for rooting percentage. However, the interaction between them was nonsignificant. In the substrate base, the highest rooting percentage $(71.11 \%)$ was identified in the cuttings inserted in perlite:peat medium and treated with $4000 \mathrm{mg}^{-1}$ IBA $(p<0.05)$. On the other hand, the treatments of IBA + NAA combinations, presented higher performance than alone IBA or NAA treatments for root length, shoot number, shoot and root densities. According to Hartmann et al. (2010), combination of IBA and NAA than either auxin alone produces more rooting and larger root systems in the cuttings of many species, which is compatible with our results.

If it is required to deal with IBA and NAA treatments separately, IBA alone treatments were found more successful than NAA alone treatments to generate higher survival, rooting and other observation parameters except from root length and shoot density. The superiority of IBA compared to NAA for AR of the cuttings has also been revealed in other plant species such as Paeonia 'Yang Fei Chu Yu' (Guo et al., 2009) and Macleania rupestris (Veloza et al., 2014) because of its several advantages such as greater stability to light than others (Kurepin et al., 2011; Pacurar et al., 2014), localized action, persistence and low toxicity (Fachinello et al., 1995). 
Expt. II was designed on 09 June to explore the effects of three CPAs including control and four substrates (perlite, peat, peat: sand, cocopeat:sand) on rooting of $E$. manipuliflora cuttings. The interaction between substrate and CPA was found very significant $(p<0.001)$ for survival and AR formation. Also, very significant differences were detected among the substrates $(p<0.001)$ and CPAs $(p<0.01)$ for both parameters. However, the difference among CPAs derived from the control treatment without auxin. In the separate one-way variance analysis of rooting performance in each substrate, the difference among CPAs was determined significant for only cocopeatbased substrate $(p<0.01)$. The highest survival and also rooting ratio occurred in cocopeat-based medium. Control treatment of cocopeat-based substrate was the superior and showed 2.5 and 3 -fold increase in rooting percentage than the I. and II.CPAs, respectively. The survival $(84 \%)$ and rooting $(76 \%)$ ratios of the control treatment in cocopeat:sand were the highest values among overall treatments of Expt. I and II.

Cocopeat known also as coconut coir dust is an agricultural by-product (Hume, 1949) obtained after the extraction of fiber from the mesocarp or husk of coconut (Cocos nucifera L.) fruit (Abad et al., 2002; Awang et al., 2009). Even though it has been recognized since 1940s (Hume, 1949), it has attracted the attention particularly for the last 20 years (Lowry, 2015). It has been accepted to be a good media component (Awang et al., 2009) and a peat substitute because of its several advantages such as perfect drainage, absence of weeds and pathogens, slower decomposition, acceptable $\mathrm{pH}$, cation exchange capacity, electrical conductivity and easier wettability (Cresswell, 1992; Meerow, 1994). On the other hand, cocopeat is known to have rather high water holding capacity resulting poor air-water relationship and causing to low aeration within the medium (Abad et al., 2002; Awang et al., 2009). However, it is possible to eliminate this disadvantage by incorporation of different coarser materials into cocopeat (Bunt, 1988; Awang et al., 2009). As a suitable substrate, cocopeat has been used in various plant species for different aims such as potting mixture of Asplenium nidus (Ainuddin and Najwa, 2009), Pistacia lentiscus and Quercus ilex (Vallejo et al., 2012), germination of sweet corn seeds (El-Hamed et al., 2011), transplanting of tomato (Arenas et al., 2002) and Sambucus seedlings (Cano et al., 2007), acclimatization and hardening of Mentha arvensis (Phatak and Heble, 2002), apple (Modgil et al., 2009) and Ericaceous in vitro plants from six genera not including Erica (Scagel, 2003), and AR of the cuttings of Nerium oleander (Ochoa et al., 2003), Calluna vulgaris and Rhododendron cultivars (Matysiak and Nowak, 2009). In most of these studies, cocopeat has been used as a media enhancer in low ratios, up to most $50 \%$, in peat, perlite, vermiculite and sand mixtures, not alone or exceeding half of the medium. In current study, we complied the suggestion of seller company and used 5:1 (v/v) cocopeat:sand mixture. This ratio (80\%) seems quite higher compared to other combinations in literature. For instance, Matysiak and Nowak (2009) tested six coir substrates having different ratio of coir up to $35 \%$, sphagnum peat moss, perlite and sand for rooting of the cuttings of ornamental ericaceous plants, Calluna vulgaris and Rhododendron cultivars. The best rooting mixture for $C$. vulgaris were those containing at least $15 \%$ of coir, while $20 \%$ for Rhododendron. In addition, increasing amounts of coir above $20 \%$ resulted in decreased rooting ratios for ericaceous plants, especially for Rhododendron 'Roseum Elegans'. Arenas et al. (2002) also reported a reduced plant growth for tomato transplants grown in coir amended media exceeding $50 \%$.

Seemingly, the rooting result obtained from the control treatment of cocopeat-based substrate in the present work is not in accordance with them, but revealed the most 
successful rooting ratios. The reasons for this result might possibly be attributed to the plant type of E. manipuliflora, which is an Ericaceous species producing ericoid mycorrhizas, and Scagel (2003)'s statement. According to her, cocopeat contains a great number of free-living phosphate solubilizing, acid phosphatase producing and nitrogenfixing rhizobacteria, and thus it is a proper media amendment for growing Ericaceous species. In addition, Scagel (1999) found the rooting of Ericaceous plants increased linearly with increasing stem protein content. During the sampling of cuttings, it is not possible to change protein level of cuttings. However, it can be raised with some cultural methods such as special media mixtures, fertilizers or mycorrhizal fungi application. Cocopeat use in media compositions can increase protein levels of stems, leaves and roots of the plants. For instance, Scagel (1999) determined higher protein level in Kalmia latifolia plants growing in an amended medium with cocopeat than the plants in the medium without cocopeat. Hence, changing media ingredient or treatment of mycorrhizal fungi may alter tissue protein levels of ericaceous plant cuttings and affect AR of them as suggested by Scagel (1999).

The literature is lacking for isolation and inoculation treatment of ericoid mycorrhizas in E. manipuliflora. However, we know how the predominant species of typical sclerophyllous Mediterranean vegetation (Macchia) are rich in mycorrhizal diversity from Maremmani et al. (2003)'s study. In their mycorrhizal screening in 82 species belonging to 46 plant families in two native Mediterranean Macchia sites from Italy and Greece, they determined $83 \%$ and $90 \%$ of the plant species, respectively, had mycorrhizas. One of the screened species was E. arborea L. and ericoid mycorrhizas were found only in this species. E. arborea mycorrhizas are not only limited to ericoid ones since plant roots can form multiple mycorrhizal interactions with various fungal partners from different taxa as reported by Bergero et al. (2000). They identified about 150 fungal isolates from E. arborea roots. Additionally, Bergero et al. (2003) used $E$. arborea as a bait plant and found ericoid mycorrhizal fungi persist and sustain mycorrhizal ability in habitats lacking ericaceous host as in the case of Pernettya macrostigma (Brook, 1952) and Calluna vulgaris (Pearson and Read, 1973). Therefore, E. manipuliflora as a close relative of E. arborea and a predominant sclerophyllous Macchia species is also most likely in mycorrhizal association in nature. Hereby, a mycorrhizal inoculation in culture stage may probably help its successful production as in other Ericaceous plants such as C. vulgaris (Gebhardt and Friedrich, 1987), Vaccinium corymbosum (Scagel et al., 2005), V. meridionale (Ávila Díaz-Granados et al., 2009), Leucothoe axillaris and Pieris japonica (Zinati et al., 2011). However, as we did not make an inoculation intentionally, the successful survival and rooting results of the control treatment in cocopeat-based media might be explained with again Scagel (2003)'s above mentioned claim. Cocopeat imported from tropical regions and used in our study might presumably have contained some indigenous microbial and mychorrhizal entities even if in low populations, and such quantity is enough to initiate the required mycorrhizal inoculation with an ericaceous species (Ibrahim Ortas, Cukurova University, Adana, Turkey, personal communication). According to Zinati et al. (2011), microbial entities containing natural ericoid roots and soil having a mix of rhizospheric and nonrhizospheric bacteria, mycorrhizal and saprotrophic fungi have potential to improve plant growth by enhancing nutrient uptake. Vosatka et al. (1999) also reported that colonization may reduce transplant mortality and increase crop uniformity and productivity in the soil-less media containing low populations of indigenous mycorrhizal fungi. Indeed, the highest survival (84\%) and rooting (76\%) 
ratio took place in cocopeat-based media in our work. If the information of "more than $90 \%$ of terrestrial plants are associated with mycorrhizas installing a permanent and intimate mutualistic symbiosis" (Strack et al., 2003) and "native genotypes are more dependent on mycorrhizas compared to cultivated forms" (Clement and Habte, 1995) is considered accurate, mycorrhizal requirements of native plants should be taken into consideration during their culture. Thus, mycorrhizal inoculation seems required for also E. manipuliflora production, and it is recommended for future studies.

In terms of cutting collection time, the cuttings sampled on 09 June (Expt. II) were better than the ones collected on 10 November (Expt. I) for AR formation and growth, which was possibly caused by the cuttings carrying fresher leaf shoots in Expt. II. However, the time span between taking cuttings from donor plant and inserting them to a substrate is another considerable issue for higher AR in E. manipuliflora. In our previous small-scale study (Ari et al., 2015) E. manipuliflora cuttings were taken from stock plants next to glasshouse on 19 June, inserted in $\approx 20 \mathrm{~min}$ in cocopeat:sand $(5: 1$ $\mathrm{v} / \mathrm{v})$ mixture and revealed the highest AR (80\%). Hence, moisture content of the cuttings should be taken into account and it is recommended to cut off and treat $E$. manipuliflora cuttings in the shortest time for minimum moisture loss especially in summer months.

In regard to useful auxin type, the auxin use in liquid formulations in Expt.I seems more successful than the powdered auxin use in Expt. II to form higher rooting ratio (up to $71 \%$ versus $30 \%$ ). However, it is not possible to talk about an essential requirement for PGR use in either liquid or powdered formulation in present work because of the higher performances of control treatments without auxin. The Heather Society also does not recommend to use rooting hormones for hardy heathers (THS, 2015b) and evaluate E. manipuliflora among the hardy Ericas (THS, 2015a).

As a remarkable observation, the resulting AR in the cuttings took place from leaf nodes, not from bottom end of the cuttings in both Expt. I and II. This kind of root formation was also stated by The Heather Society for E. carnea initiating to form its roots always from a leaf nodule. However, the same Society stated different rooting style for E. cinerea, whose roots appear from the cutting base (THS, 2015b). According to Mahlstede and Watson (1952), AR could be initiated directly from the vascular tissue like cambium and secondary phloem parenchyma in Ericales, as in the case of Vaccinium corymbosum (Veloza et al., 2014). In appearance, rooting style is not the same for all Ericaceous species. We do not know the origin of root initials for AR formation in E. manipuliflora cuttings since we did not make a histological study. However, Zhang et al. (2009) examined the anatomical origin of Feijoa sellowiana, rooted in E. manipuliflora style, and reported that there were sequential and cyclical cells in the phloem and no root primordium in the Feijoa cuttings.

We observed another notable genesis that several mini individual detached shootings with a few leaf pieces broken from cuttings and fallen into growing media formed healthy, long adventitious roots. As reported by Ludwig-Muller et al. (2005), adventitious roots are less predictable in their cellular origin than lateral roots. They might occur from the cambium or from calli in the case of detached stem cuttings. According to Hartmann et al. (2010), leaves serve as the resource of endogenous auxins and carbohydrates, which implements a stimulating action on AR initiation in cuttings (Veloza et al., 2014). Ericoid mycorrhizal fungi may also produce hormones or stimulate plant production of hormones inducing AR development and growth (Scagel et al., 2005). On the other hand, using exogenous hormones may diminish the effects of 
mycorrhizal fungi on AR development as in the cuttings of Vaccinium meridionale (Avila Diaz-Granados et al., 2009). All these information might explain how mini individual E. manipuliflora shootings brought about AR without hormone requirement and why control cuttings in cocopeat-based medium rooted more successfully than the cuttings treated with auxins. Therefore, the use of $4-5 \mathrm{~cm}$ fresh leafy minicuttings consisting of a few leaf nodes with needle leaves is suggested for AR formation and consequently for vegetative production of E. manipuliflora for future studies as used in plant production of several ornamental plants lately. Also, it is proposed to culture minicuttings in the viols instead of benches containing cocopeat-based growing media, and may be inoculated with ericoid mycorrhizas, but without any PGR use.

In conclusion, E. manipuliflora cuttings taken in June and cultured in cocopeat:sand (5:1) mixture without any auxin usage revealed the highest survival $(84 \%)$ and rooting (76\%) ratios among the cuttings in overall treatments. This result indicated that exogenous auxin use is not essential for adventitious rooting of E. manipuliflora cuttings. It might be used as rooting enhancer in the studies including cocopeat-free substrates. But it has a reducing effect in cocopeat-based media. The superiority of cocopeat-based medium to generate the highest adventitious rooting originated most likely from the small amount of indigenous microbial and mychorrhizal entities carried with the cocopeat. Thus, mycorrhizal inoculation seems required for E. manipuliflora production. For future studies, using of mycorrhizal inoculation or minicuttings in eco friendly cocopeat-based media has the potential to increase the present AR ratio.

Acknowledgements. Authors gratefully thank to The Scientific and Technological Research Council of Turkey (TUBITAK) for supporting 106G020 project, sub-project of 105G068-TUBITAK-KAMAG-1007 and Prof. Mehmet Ziya Firat for his valuable advices on statistical analysis.

\section{REFERENCES}

[1] Abad, M., P. Noguera, R. Puchades, A. Maquieira and V. Noguera. 2002. Physicochemical and chemical properties of some coconut dusts for use as a peat substitute for containerized ornamental plants. Biores. Technol., 82: 241-245.

[2] Ainuddin, N. and D. N. Najwa. 2009. Growth and physiological responses of Asplenium nidus to water stress. Asian Journal of Plant Sciences, 8 (6): 447-450.

[3] Akkol, E. K., E. Yesilada and A. Guvenc. 2008. Valuation of anti-inflammatory and antinociceptive activities of Erica species native to Turkey. Journal of ethnopharmacology, 116 (2): 251-257.

[4] Arenas, M., C. S .Vavrina, J. A. Cornell, E. A. Hanlon EA and G. J. Hochmuth. 2002. Coir as an alternative to peat in media for tomato transplant production. HortScience, 37 (2): 309-312.

[5] Ari, E., E. Gurbuz and B. Sayin. 2010. The Perspective of the Landscape Sector in Antalya to The Use of Natural Plants. In: IV. National Ornamental Plant Congress. Publisher: ALATA Horticultural Resesarch Institute, Alata, Mersin, Turkey. p: 348-358 (in Turkish).

[6] Ari, E., E. Gurbuz and S. Tugrul Ay. 2014. Seed Germinations of 20 Wild Species Growing in Antalya, Turkey, with Outdoor Ornamental Plant Potential. In: Fifth International Scientific Agricultural Symposium (AGROSYM 2014). Original scientific paper: 10.7251/AGSY1404439A. Publisher: University of East Sarajevo, Faculty of Agriculture, Bosnia. p: 439-445. 
[7] Ari, E., E. Gurbuz, S. Tugrul Ay, O. Karaguzel and A. Ozcelik. 2015. Assessing vegetative production studies of 22 native plant species growing in Antalya, Turkey, with potential as outdoor ornamental plant. In: $25^{\text {th }}$ EUCARPIA Symposium -Section Ornamentals. Publisher: Acta Hortic,1087: 281-288.

[8] Avila Diaz-Granados, R. A., O. J. Orozco Silva, G. L. Moreno, S. Magnitskiy and A. Rodriguez. 2009. Influence of mycorrhizal fungi on the rooting of stem and stolon cuttings of the Colombian blueberry (Vaccinium meridionale Swartz). International Journal of Fruit Science, 9 (4): 372-384.

[9] Awang, Y., A. S. Shaharom, R. B. Mohamad and A. Selamat. 2009. Chemical and physical characteristics of cocopeat-based media mixtures and their effects on the growth and development of Celosia cristata. American Journal of Agricultural and Biological Sciences, 4 (1): 63-71.

[10] Baytop, T. 1999. Turkiye'de Bitkiler ile Tedavi - Gecmiste ve Bugun. $2^{\text {nd }}$ ed. Nobel Tip Kitabevi, Istanbul. (in Turkish).

[11] Bergero, R., S. Perotto, M. Girlanda, G. Vidano and A. M. Luppi. 2000. Ericoid mycorrhizal fungi are common root associates of a Mediterranean ectomycorrhizal plant (Quercus ilex). Mol Ecol, 9: 1639-1649.

[12] Bergero, R., M. Girlanda, F. Bello, A. Luppi and S. Perotto. 2003. Soil persistence and biodiversity of ericoid mycorrhizal fungi in the absence of the host plant in a Mediterranean ecosystem. Mycorrhiza, 13 (2): 69-75.

[13] Brook, P. J. 1952. Mycorrhiza of Pernettya macrostigma. New Phytol, 51: 388-397.

[14] Brzuszek, R. F. and R. L. Harkess. 2009. Green industry survey of native plant marketing in the southeastern United States. HortTechnology, 19 (1): 168-172.

[15] Bunt, A. C. 1988. Media and Mixes for Container-Grown Plants. 1st Ed., Springer, London, ISBN: 10: 0046350160.

[16] Cano, A., J. M. Perez-Perez and M. Acosta. 2014. Adventitious Root Development in Ornamental Plants: Insights from Carnation Stem Cuttings. In: Root Engineering. Springer, Berlin. p: 423-441.

[17] Clement, C. R. and M. Habte. 1995. Genotypic variation in vesicular-arbuscular mycorrhizal dependence of the pejibaye palm. J.of Plant Nutrition, 18 (9): 1907-1916.

[18] Cresswell, G. C. 1992. Coir dust-A viable alternative to peat? In: Proceedings of the Australian Potting Mix Manufacturers' Conference. Sierra, Sydney, Australia.p: 1-5.

[19] El-Hamed, K., M. Elwan and W. Shaban. 2011. Enhanced sweet corn propagation: studies on transplanting feasibility and seed priming. Vegetable Crops Research Bulletin, 75: 31-50.

[20] Englert, J. M., C. Barrack and D. Woolston. 1996. Germination and Growth of Four Species of Ericaceous Plants. HortScience, 31 (4): 633-633.

[21] Fachinello, J.C., A. Hoffmann, J. C. Nachtigal, E. Kersten and G.D.L. Fortes. 1995. Propagação de plantas frutíferas de clima temperado, $2^{\text {nd }}$ ed.UFPEL-Ed. Universitaria,Pelotas,Brasil (in Portuguese)

[22] Fagundez, J. and I. Izco. 2011. Seed morphology and systematics of the European species of Erica L. sect. Gypsocallis Salisb. (Ericaceae). Plant Biosystems, 145 (1): 182-190.

[23] Fornes, F., D. Mendoza-Hernandez, and R.M. Belda. 2013. Compost versus vermicompost as substrate constituents for rooting shrub cuttings. Spanish Journal of Agricultural Research, 11 (2): 518-528.

[24] Gebhardt, K. and M. Friedrich. 1987. Micropropagation of Calluna vulgaris cv. 'H.E. Beale'. Plant Cell Tiss. Org. Cult. 9: 137-145.

[25] Guo, X.F., X.L. Fu, D.K. Zang and Y. Ma.2009. Effect of auxin treatments, cuttings' collection date and initial characteristics on Paeonia 'Yang Fei Chu Yu' cutting propagation. Scient. Hort, 119: 177-181.

[26] Guvenc, A. and G. Kendir G. 2012. The leaf anatomy of some Erica taxa native to Turkey. Turkish Journal of Botany, 36 (3): 253-262.

[27] Hamill, N. 2005. Natives near and far. Ornamental Outlook, 14 (6): 31-32. 
[28] Hume, E.P. 1949. Coir dust or cocopeat - a by-product of the coconut. Economic Botany, 3: 42-45.

[29] Jones, A.W. 1987. Notes on Erica manipuliflora, E. vagans and their hybrids. Heather Society Yearbook 1987: 51-57.

[30] Hartmann, H., D. Kester, F. Davies and R. Geneve. 2010. Plant propagation: Principles and practices, 8th ed. Prentice Hall, Upper Saddle River, NJ.

[31] Kotis, M., T.A.Yupsanis, T.D. Syros and A.S. Economou. 2009. Peroxidase, acid phosphatase, RNase and DNase activity and isoform patterns during in vitro rooting of Petunia $\times$ hybrida microshoots. Biologia Plantarum, 53 (3): 530-38.

[32] Kurepin, L., T. Haslam, A. Lopez-Villalobos, G. Oinam and E. Yeung. 2011. Adventitious root formation in ornamental plants: II. The role of plant growth regulators. Prop. of Ornamental Plants, 11: 161-171.

[33] Ling, W.X., G. Zhu and Z. Zhong. 2013. Effect of IBA on rooting from softwood cuttings of'tetraploid locust'and associated biochemical changes. Pakistan Journal of Botany, Karachi, 45 (5): 1801-1806.

[34] Lowry, B.K. 2015. Zinnia Growth and Water Use Efficiency in a Rate Study of Coconut Coir Pith and Sphagnum Peat Moss in Container Growing Substrates. Ph.D.dissertation, The Ohio State Univ.

[35] Ludwig-Müller, J., A. Vertocnik and C.D. Town. 2005. Analysis of indole-3-butyric acidinduced adventitious root formation on Arabidopsis stem segments. Journal of experimental botany, 56 (418): 2095-2105.

[36] Mahlstede, J. and D. Watson. 1952. An anatomical study of adventitious root development in stems of Vaccinium corymbosum. Bot. Gaz. 113 (3): 279-285.

[37] Maremmani, A., S. Bedini, I. Matosevic, P.E. Tomei and M. Giovannetti. 2003. Type of mycorrhizal associations in two coastal nature reserves of the Mediterranean basin. Mycorrhiza, 13 (1): 33-40.

[38] Matysiak, B. and J. Nowak. 2008. Coir substrates for rooting of ornamental ericaceous plants. Propagation of Ornamental Plants, 8 (2): 76-80.

[39] McClintock, D. 1989. The heathers of Europe and adjacent areas. Botanical journal of the Linnean Society, 101: 279-289.

[40] Meerow, A.W. 1994. Growth of two subtropical ornamentals using coir (coconut mesocarp pith) as a peat substitute. HortScience, 29: 1484-1486.

[41] Modgil, M., T. Sharma and M. Thakur. 2009. Commercially feasible protocol for rooting and acclimatization of micropropagated apple rootstocks. Acta Hortic., 839: 209-14.

[42] Norcini, J. 2006. Native plants: An overview. Florida Coop. Ext. Serv., Inst.Food Agr.Sci,Florida Univ.

[43] Ochoa, J., S. Banon, J.A. Fernandez, A. Gonzalez and J.A. Franco. 2003. Influence Of Cutting Position and Rooting Media On Rhizogenesis In Oleander Cuttings. Acta Hort., 608: 101-106.

[44] Pacurar, D.I., I. Perrone and C. Bellini. 2014. Auxin is a central player in the hormone cross-talks that control adventitious rooting. Physiologia plantarum, 151 (1): 83-96.

[45] Pearson, V. and D.J. Read. 1973. The biology of mycorrhiza in the Ericaceae. I. The isolation of the endophyte and synthesis of mycorrhizas in aseptic culture. New Phytol., 72: 371-379.

[46] Phatak, S.V. and M.R. Heble. 2002. Organogenesis and terpenoid synthesis in Mentha arvensis. Fitoterapia, 73 (1): 32-39.

[47] Piotto, P., G. Bartolini, F. Busssotti, A.A.C. Garcia, I. Chessa, C. Ciccarese, L. Ciccarese, R. Crosti, F.J. Cullum, A. Di Noi, ..., and T. Tylkowski. 2001. Fact sheets on the propagation of Mediterranean trees and shrubs from seed. In: Seed propagation of Mediterranean trees and shrubs (P. Piotto, A. Di Noi, Eds). APAT, Rome. p: 11-51.

[48] Pipinis, E., M. Aslanidou, O. Mavrokordopoulou and P. Smiris. 2006. Treatments improving seed germination of Cistus creticus, Erica arborea and Erica manipuliflora. Management and Development of Mountainous and Island Areas: 57-61. 
[49] Scagel, C.F. 1999. Regulating Root Growth in Ericaceous Plant Propagation. In Combined Proceedings-International Plant Propagators Society, IPPS 1998, 1999. Vol. 49: 589-592.

[50] Scagel, C.F. 2003. Growth and nutrient use of ericaceous plants grown in media amended with sphagnum moss peat or coir dust. HortScience, 38 (1): 46-54.

[51] Scagel, C.F., A. Wagner and P. Winiarski P. 2005. Inoculation with ericoid mycorrhizal fungi alters root colonization and growth in nursery production of blueberry plants from tissue culture and cuttings. Small fruits review, 4 (4): 113-135.

[52] Stevens, P.F. 1978. Erica L. In: Davis PH (ed.) Flora of Turkey and the Aegean Islands, Edinburgh: Edinburgh University Press. Vol. 6: 95-97.

[53] Strack, D., T. Fester, B. Hause, W. Schliemann and M.H. Walter. 2003. Review paper: Arbuscular mycorrhiza: Biological, chemical, and molecular aspects. J. of chemical ecology, 29 (9): 1955-1979.

[54] THS. 2015a. The Heather Society. Erica Hardy - Erica manipuliflora: whorled heath. https://www.heathersociety.org/category/heathers/erica-hardy/ (Accession on 15.06.2015).

[55] THS. 2015b. The Heather Society. How do I propagate using cuttings? https://www.heathersociety.org/growing-aftercare-faq/ (Accession on 15.06.2015).

[56] TPDS. 2015.. Turkish Plants Data Service. www.tubives.com/index.php?sayfa=1\&tax_id=6195 (Accession on: 17.05.2015)

[57] TSMS. 2015. The Turkish State Meteorological Service. Ankara, Turkey.

[58] Tuzlaci, E. and P. Eryasar Aymaz. 2001. Turkish folk medicinal plants, Fitoterapia, 72 : 323-343.

[59] UPOV. 2015. http://www.upov.int/genie/en/dus.jsp?id=2121 (Accession on 15.06.2015).

[60] Vallejo, V.R., A. Smanis, E. Chirino, D. Fuentes, A. Valdecantos and A. Vilagrosa. 2012. Perspectives in dryland restoration: approaches for climate change adaptation. New Forests, 43 (5-6): 561-579.

[61] Veloza, C., S. Duran, S. Magnitskiy and H. Lancheros. 2014. Rooting Ability of Stem Cuttings of Macleania rupestris Kunth AC Sm., a South American Fruit Species. Int. Jour. of Fruit Sci., 14 (4): 343-361.

[62] Vosatka, M., J. Rydlova and R. Malcova. 1999. Microbial inoculations of plants for revegetation of disturbed soils in degraded ecosystems. In: KovAR P. (ed.), Nature and culture in landscape ecology. Proceedings of the CZ-IALE Conference, The Karolinum Press, Prague. P 303-317.

[63] Zinati, G.M., J. Dighton and A.J. Both. 2011. Fertilizer, irrigation, and natural ericaceous root and soil inoculum (NERS): Effects on container-grown ericaceous nursery crop biomass, tissue nutrient concentration, and leachate nutrient quality. HortScience, 46 (5): 799-807. 